\title{
ANALISIS KUANTITATIF NEODIMIUM, PRASEODIMIUM, CERIUM, DAN LANTANUM DALAM MONASIT DENGAN KCKT PERTUKARAN ION
}

\author{
Herman $^{1)}$, Husein H. Bahti ${ }^{2)}$, Muljadji Agma ${ }^{2)}$ \\ Kelompok Bidang Ilmu Kimia Farmasi, Fakultas Farmasi Universitas Mulawarman, \\ Samarinda \\ e-mail: herman@farmasi.unmul.ac.id ${ }^{1)}$ \\ Laboratorium Penelitian Kimia, FMIPA Universitas Padjadjaran, Bandung ${ }^{2)}$
}

\begin{abstract}
Neodymium, Praseodymium, Cerium, and Lanthanum are rare earth elements with considerably high concentration in monazite and xenotime. Samples used in this research are monazite sands from PT Timah Bangka and obtained from Dowa Mining product. The determination and separation of these rare earth elements carried out with ion exchange HPLC method using ion exchanger column Supelcosil LC-SCX with column length $25 \mathrm{~cm}$, diameter $4.6 \mathrm{~mm}$ and particle size $5 \mu \mathrm{m}$, and using conductometer detector of Waters 432 type. The optimum condition for these rare earth elements were: using ethylendiamin solution of $1.50 \mathrm{mM}$, and tatrate acid $2.00 \mathrm{mM}$ as moving phase and complexing agent at $\mathrm{pH} 4.5$ with flow rate $0.8 \mathrm{~mL}$ per minute and sample volume $10 \mu \mathrm{L}$. Research results showed that ion exchange HPLC method can be used to separate and to determinate the concentration of Neodymium, Praseodymium, Cerium, and Lanthanum. Chromatograms obtained of these four of rare earth elements were well separated. This was showed from their resolutions $(R)$ which range from 2 to 4 at concentration 100 ppm for Neodymium, Praseodymium, Cerium, and Lanthanum with retention time 9.66, 10.87, 13.42, 16.29 minutes respectively. The concentration of Neodymium, praseodymium, cerium, and lanthanum in monazite (w/w) were $4.580 \pm 0.003,7.860 \pm 0.002,4.200 \pm 0.003,4.160 \pm 0.005 \%$ respectively.
\end{abstract}

Key Words: Neodymium, Praseodymium, Cerium, Lanthanum, Monasit, HPLC

\begin{abstract}
ABSTRAK
Neodimium, Praseodimium, Serium, dan Lantanum merupakan unsur tanah jarang dengan kadar tinggi yang terdapat dalam monasit dan senotim. Sampel yang digunakan dalam penelitian ini adalah pasir monasit dari PT Timah Bangka yang diperoleh melalui hasil Dowa Mining. Penentuan dan pemisahan unsur tanah jarang ini dilakukan dengan metode KCKT pertukaran ion menggunakan kolom penukar ion Supelcosil LC-SCX panjang kolom $25 \mathrm{~cm}$, diameter 4,6 mm, dan ukuran partikel $5 \mu \mathrm{m}$ dengan menggunakan detektor konduktometer jenis Waters 432. Kondisi optimum pemisahan unsur tanah jarang: menggunakan larutan etilendiamin $1,50 \mathrm{mM}$ dan asam tartrat $2,00 \mathrm{mM}$ sebagai fasa gerak dan pengompleks pada $\mathrm{pH}$ 4,5 dengan kecepatan alir $0,8 \mathrm{~mL} /$ menit dan volume sampel $10 \mu \mathrm{L}$. Hasil penelitian menunjukkan bahwa metode KCKT pertukaran ion dapat digunakan untuk memisahkan dan menentukan kandungan Neodimium, Praseodimium, Serium, dan Lantanum. Kromatogram campuran dari keempat unsur tanah jarang yang diperoleh dapat terpisah dengan baik, hal ini dapat dilihat dari resolusinya $(\mathrm{R})$ berkisar 2 sampai 4 pada konsentrasi 100 ppm untuk Neodimium, Praseodimium, Serium, dan Lantanum dengan waktu retensi berturut-turut 9,66; 10,87; 13,42; 16,29 menit. Kandungan Neodimium, Praseodimium, Serium, dan Lantanum
\end{abstract}


Analisis Kuantitatif Neodimium, Praseodimium, Cerium, Dan Lantanum Dalam Monasit Dengan KCKT Pertukaran Ion

dalam monasit (b/b) berturut turut yaitu: 4,580 $\pm 0,003 ; 7,860 \pm 0,002 ; 4,200 \pm 0,003$; 4,160 $\pm 0.005 \%$, dengan batas deteksi berturut-turut yaitu: 261, 386, 424, $334 \mathrm{ng}$.

Kata Kunci: Neodimium, Praseodimium, Serium, Lantanum, Monasit, KCKT

\section{PENDAHULUAN}

Unsur tanah jarang mempunyai peranan penting dalam pengembangan ilmu pengetahuan dan industri-industri dengan teknologi tinggi. Dalam teknologi modern unsur tanah jarang merupakan salah satu golongan bahan penunjang untuk menciptakan barang-barang inovasi serta produk khusus lainnya. Umumnya unsur tanah jarang terdapat dalam bentuk mineral-mineralnya. Mineral utama yang menjadi sumber unsur tanah jarang adalah monasit, basnasit, dan senotim. Mineralmineral ini terdapat dalam pasir pantai sebagai hasil samping dari penambangan bijih timah yang terdapat di kepulauan Bangka, Belitung, dan Singkep.

Metode-metode pemisahan yang banyak digunakan untuk memperoleh unsur tanah jarang dengan tingkat kemurnian yang tinggi adalah dengan menggunakan teknik pengendapan bertingkat, kristalisasi bertingkat, ekstraksi, dan kromatografi cair kinerja tinggi pertukaran ion. Namun dari keempat metode hanya kromatografi cair kinerja tinggi pertukaran ion merupakan metode yang lebih efektif dan efisien ditinjau dari aspek ekonomis karena sedikit menggunakan bahan kimia dibanding dengan metode lainnya.

Pemisahan unsur tanah jarang dengan menggunakan KCKT telah dilakukan sejak lama dengan menggunakan berbagai kolom diantaranya: kolom C18, kolom penukar anion, kolom penukar kation.

Pemilihan zat pengompleks untuk pembentukan ion kompleks memberikan perbedaan yang signifikan bagi pemisahan yang cepat dan sempurna dari sebagian besar ion unsur tanah jarang. Kesetimbangan dan pembentukan ion dalam proses pertukaran ion memberikan variasi yang banyak bagi pemisahan unsur menggunakan resin penukar anion dan kation (Cochrane, 1986).

Penelitian dan pengembangan kromatografi terus dilakukan untuk mencari metode yang lebih unggul, yang banyak dilakukan saat ini adalah dengan KCKT pertukaran ion.

Huang Wei-Xiong (1991) melakukan pemisahan unsur tanah jarang dengan metode KCKT pertukaran ion menggunakan kolom C18. Teknik ini hanya dapat memisahkan dua unsur tanah jarang yaitu samarium dan geodimium, sedangkan unsur tanah jarang lainnya masih menyatu dalam satu puncak.

Hadad, (1990) mengemukakan bahwa metode post column merupakan salah satu metode yang dipilih untuk mendeteksi unsur tanah jarang dengan sistem detektor konduktometer. Keberhasilan teknik ini tergantung pada laju alir yang konstan dari eluen dan reagen serta efisiensi sistem pencampuran sehingga didapat waktu retensi yang cepat, gangguan yang kecil serta volume injeksi yang kecil untuk mendapatkan puncak tanpa pelebaran pita. Reagen post column yang digunakan untuk memisahkan unsur tanah jarang adalah PAR atau 4,2-pyridilazoresorsinol, merupakan suatu indikator warna yang dapat bereaksi dengan sebagian besar unsur transisi dan lantanida. Unsur tanah jarang dapat bereaksi dengan PAR dan juga dapat dipisahkan dengan menggunakan penukar anion dan kation, telah berhasil memisahkan memisahkan 14 unsur 
lantanida dengan waktu retensi kurang dari 20 menit.

Framudia (2004) telah berhasil melakukan pemisahan serium dalam senotim secara KCKT penukar kation lemah pada kondisi optimum pemisahan: kecepatan alir 0,8 $\mathrm{mL} / \mathrm{menit}$; fasa gerak etilendiamin konsentrasi $5 \mathrm{mM}$ dengan ligan pengompleks asam tartrat $10 \mathrm{mM}$; $\mathrm{pH} \mathrm{3,5}$ dan volume injeksi $10 \mu \mathrm{L}$.

Penelitian ini merupakan pengembangan dari metode pemisahan unsur tanah jarang dengan menggunakan KCKT pertukaran ion, yaitu akan dilakukan pemisahan unsur tanah jarang seperti neodimium dan praseodimium dengan KCKT pertukaran ion untuk kolom dan eluen yang sama. Penelitian ini diharapkan dapat memisahkan dan menentukan besar kandungan dari neodimium dan praseodimium yang terdapat dalam monasit dan senotim dengan metode KCKT pertukaran ion.

\section{METODE PENELITIAN}

\section{Alat}

Alat yang digunakan dalam penelitian ini yaitu peralatan gelas yang biasa digunakan di laboratorium kimia, neraca analitis digital, $\mathrm{pH}$ meter, sonikator, konduktometer, penyaring Millipore, seperangkat sistem KCKT Waters yang terdiri atas pompa, detektor konduktivitas (Waters 432 detector), kolom penukar kation kuat supelcosil LC-SCX dengan panjang kolom $25 \mathrm{~cm}$, diameter $4,6 \mathrm{~mm}$, dengan ukuran partikel $5 \mu \mathrm{m}$, dan KCKT Waters.

\section{Bahan}

Bahan yang yang diteliti (Sampel) adalah Pasir Monasit yang diambil dari PT Timah
Bangka. Bahan untuk Penelitian adalah semuanya berkualitas pro analisa, kecuali air Reversed Osmosis (air RO) yaitu asam klorida, asam nitrat, asam sulfat, asam tartrat, asam asetat, natrium asetat, amoniak, etilendiamin, hidrogen peroksida, serium oksida, lantanum oksida, neodimium oksida, praseodimium oksida, resin penukar kation, resin penukar anion.

\section{Pelaksanaan Penelitian}

\section{Pembuatan Fasa Gerak:}

Ke dalam gelas kimia $1 \mathrm{~L}$ yang berisi 500 $\mathrm{mL}$ air $18 \mathrm{megohm} / \mathrm{cm}$, dimasukkan $0,3 \mathrm{~g}$ asam tartrat dan 0,09 mL etilendiamin lalu diaduk hingga larut, atur $\mathrm{pH}$ dengan menambahkan natrium asetat dan asam asetat sampai $\mathrm{pH}$ 4,5 dan dipindahkan ke dalam labu ukur $1 \mathrm{~L}$ yang selanjutnya diisi dengan buffer asetat sampai tanda batas kemudian disaring dengan menggunakan millipore dan degassing dalam sonikator selama 10-15 menit.

\section{Penentuan Kondisi Optimum Kromatografi Pertukaran ion:}

Larutan blanko dan larutan standar tunggal masing-masing neodimium, praseodimium, serium, dan lantanum konsentrasi 100 ppm, masing-masing disuntikkan ke dalam sistem KCKT pertukaran ion melalui injektor sebanyak $10 \mu \mathrm{L}$. Fasa gerak yang digunakan yaitu etilendiamin 1,5 $\mathrm{mM}$ dan asam tartrat 2,0 mM sebagai pengompleks dengan variasi $\mathrm{pH} 3-5$, dengan kecepatan alir $0,8 \mathrm{~mL} / \mathrm{menit}$. Eluat dideteksi menggunakan detektor konduktometer kemudian dilakukan analisis data kromatogram.

\section{Penentuan Batas Deteksi}

Larutan standar campuran dari neodimium, praseodimium, serium, dan lantanum 
Analisis Kuantitatif Neodimium, Praseodimium, Cerium, Dan Lantanum Dalam Monasit Dengan Kckt Pertukaran Ion

dengan konsentrasi berturut-turut: 40, 20, $15, \quad 10$, dan 5 ppm masing-masing disuntikkan ke dalam sistem KCKT pertukaran ion melalui injektor sebanyak $10 \mu \mathrm{L}$. Fasa gerak yang digunakan yaitu etilendiamin $1,5 \mathrm{mM}$ dan asam tartrat 2,0 $\mathrm{mM}$ sebagai pengompleks, kondisi $\mathrm{pH}$ eluen optimum 4,5, kecepatan alir optimum $0,8 \mathrm{~mL} / \mathrm{menit}$ dan sensivitas 1 volt, selanjutnya diulangi untuk larutan standar 5 ppm dengan sensivitas 0,001 volt pada detektor konduktivity.

\section{Pemisahan UTJ Dalam Monasit}

Pemisahan unsur tanah jarang dalam monasit dilakukan sebagai berikut: larutan diencerkan dan disuntikkan ke dalam sistem KCKT pertukaran ion melalui injektor sebanyak $10 \mu \mathrm{L}$. Fasa Gerak yang digunakan yaitu etilendiamin $1,5 \mathrm{mM}$ dan asam tartrat 2,0 mM sebagai pengompleks, kondisi $\mathrm{pH}$ eluen optimum 4,5, kecepatan alir optimum $0,8 \mathrm{~mL} / \mathrm{menit}$ dan dideteksi menggunakan konduktometer. Selanjutnya dilakukan analisis data kromatogram sampel yang dibandingkan dengan kromatogram masing-masing unsur dan dihitung kandungannya.

\section{PEMBAHASAN}

Untuk memperoleh unsur tanah jarang dari bahan mineral yang memenuhi standar sangat sulit, hal ini disebabkan oleh kemiripan sifat fisika dan kimianya dari masing-masing unsur tanah jarang. Monasit merupakan sumber mineral unsur tanah jarang yang merupakan hasil samping dari pengolahan timah. Kandungan neodimium, praseodimium dalam monasit sangat besar dibanding dengan unsur tanah jarang lainnya. Oleh karena itu penelitian tentang pemisahan unsur tanah jarang tersebut perlu dan terus dikembangkan untuk memperoleh hasil yang diinginkan.

\section{Penentuan kondisi Optimum Pemisahan Unsur Tanah Jarang}

Penentuan unsur tanah jarang telah dilakukan untuk memperoleh pemisahan yang maksimum. Optimasi dilakukan dengan larutan etilendiamin dan asam tartrat sebagai eluen dan pengompleks. Keberhasilan pemisahan dengan menggunakan kromatografi pertukaran ion ini sangat ditentukan oleh $\mathrm{pH}$ eluen. Rentang pH dalam penelitian ini adalah 3 sampai 5, hal ini disebabkan karena pada kondisi $\mathrm{pH}$ di atas 5 protonasi dari etilendiamin tidak berlangsung dengan baik, sedangkan selektivitas dari pemisahan unsur ini ditentukan oleh protonasi etilendiamin oleh asam (proton), sedang pada $\mathrm{pH}$ di bawah 3, kemampuan mengompleks dari asam tartrat hilang dan sensitivitas dari kation logam turun secara signifikan. Berdasarkan hasil optimasi $\mathrm{pH}$ fasa gerak yang diperoleh pada $\mathrm{pH} 4,5$.

Optimasi yang dilakukan dalam penelitian ini meliputi: variasi komposisi etilendiamin dengan konsentrasi 1,$25 ; 1,50 ; 1,75 ; 2,00$; $2,25 \mathrm{mM}$ dan asam tartrat dengan konsentrasi 1,$25 ; 1,50 ; 1,75 ; 2,00 ; 2,25$ $\mathrm{mM}$, maka diperoleh kondisi optimum konsentrasi fasa gerak untuk memisahkan neodimium, praseodimium, serium, dan lantanum diperoleh komposisi konsentrasi 1,50 : 2,00 mM (Etilendiamin : Asam tartrat). Selanjutnya dilakukan variasi kecepatan alir mulai dari 0,$5 ; 0,6 ; 0,7$ sampai 1,0 $\mathrm{mL} / \mathrm{menit}$. Dari beberapa variasi ini diperoleh kondisi optimum pemisahan neodimium, praseodimium, serium, dan lantanum dari sampel monasit dan senotim yaitu $0,8 \mathrm{~mL} / \mathrm{menit}$. Volume injeksi $10 \mu \mathrm{L}$ dan deteksi eluat dengan menggunakan detektor konduktivitas jenis waters 432 conductivity detector. 


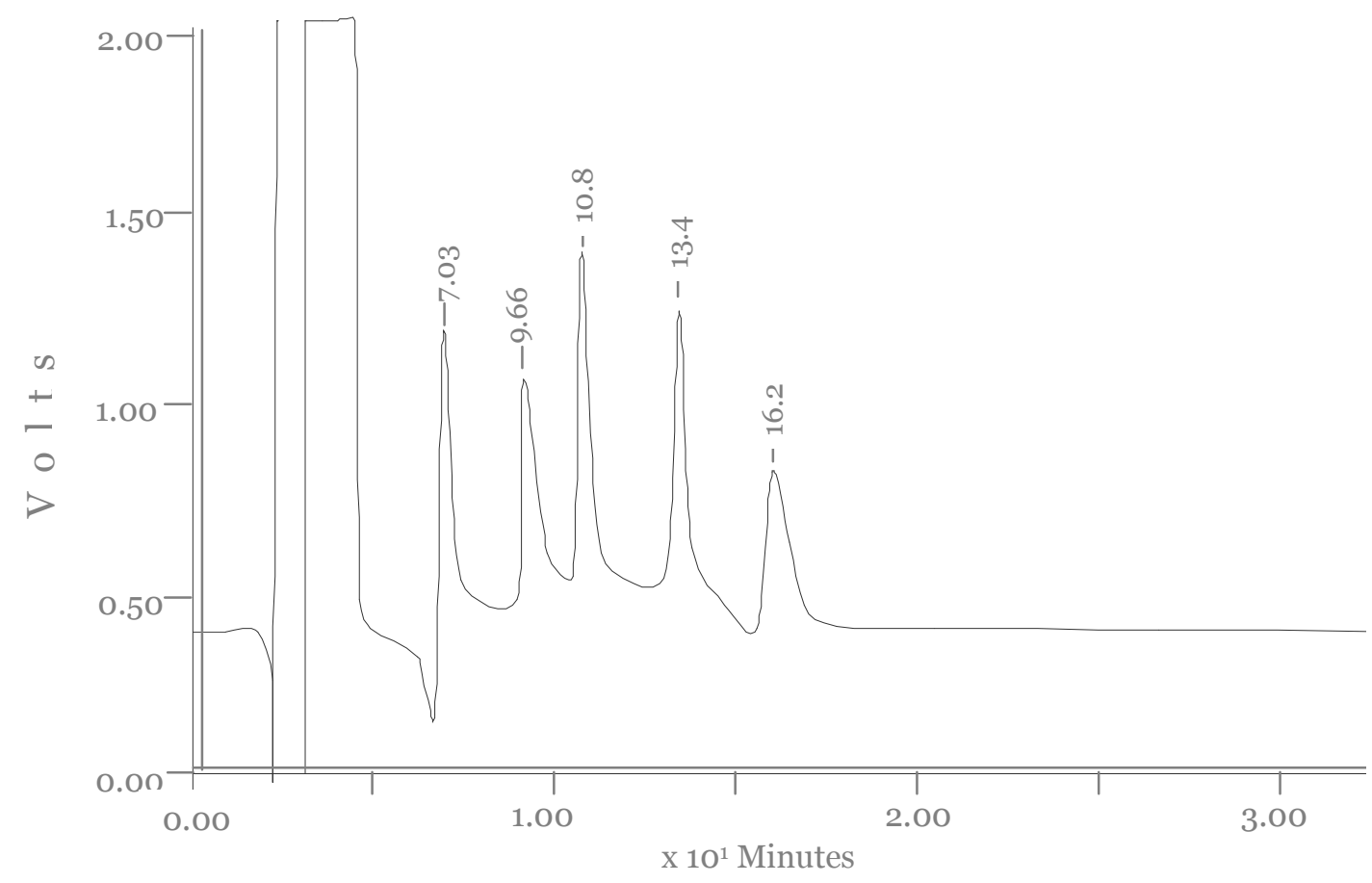

Gambar 1. Kromatogram Kromatogram Campuran Standar Neodimium, Praseodimium, Serium dan Lantanum 100 ppm

Berdasarkan hasil kromatogram larutan standar tunggal unsur tanah jarang neodimium dan praseodimium masingmasing yang telah diperoleh, selanjutnya dilakukan pengukuran untuk campuran dari keempat larutan standar unsur tanah jarang tersebut dengan konsentrasi masing-masing 100 ppm, yang dianalisis pada kondisi optimum.

Dari gambar 1 memperlihatkan pemisahan puncak masing-masing dari neodimium dan praseodimium dengan waktu retensi berturut-turut yaitu 9,$66 ; 10,87 ; 13,42$; 16,29 menit. Puncak dengan waktu retensi 7,03 menit diduga merupakan puncak ion $\mathrm{H}^{+}$dari pelarut asam sulfat. Kromatogram unsur-unsur tanah jarang menunjukkan pemisahan yang baik. Hal ini disebabkan karena ion $\mathrm{La}^{3+} ; \mathrm{Nd}^{3+}$; $\mathrm{Pr}^{3+}$ dan $\mathrm{Ce}^{3+}$ dapat membentuk kompleks dengan selektivitas yang berbeda-beda dengan fasa diam yang digunakan. Penahanan oleh fasa diam ini ditentukan oleh elektroselektivitas dari masing-masing unsur.

Jika ditinjau dari ukuran ionnya ion $\mathrm{La}^{3+}$; $\mathrm{Nd}^{3+} ; \mathrm{Pr}^{3+}$ dan $\mathrm{Ce}^{3+}$, berturut-turut masingmasing 1,$12 ; 1,13 ; 1,15$ dan $1,17 \AA$ Á (Evans, 1995) menyatakan bahwa ukuran ion sebanding dengan muatan dari masingmasing unsur tanah jarang. Semakin besar muatan suatu atom logam, semakin besar pula afinitas ionnya yang seiring dengan naiknya interaksi coulomb. Hal inilah yang menyebabkan perbedaan dalam elektroselektivitas antara ion satu dengan lainnya dalam larutan sampel.

Kromatogram hasil pemisahan pada gambar menunjukkan bahwa Fasa gerak (etilendiamin) yang berperan sebagai ion lawan membentuk spesi $\mathrm{enH}_{2}{ }^{2+}$, sehingga terjadi kesetimbangan antara gugus 
Analisis Kuantitatif Neodimium, Praseodimium, Cerium, Dan Lantanum Dalam Monasit Dengan Kckt Pertukaran Ion

karboksilat dari fasa diam dengan fasa gerak. Ion dari masing-masing unsur tanah jarang menggantikan ion lawan yaitu spesi $\mathrm{EnH}_{2}{ }^{2+}$ yang selanjutnya ditahan di kolom yang disebabkan oleh adanya interaksi elektrostatis antara gugus karboksilat dan fasa diam dengan ion unsur tanah jarang.

Penahanan ion unsur tanah jarang ini dipengaruhi oleh efek kompetisi dari gugus karboksilat dan fasa diam yang ditempati oleh spesi $\mathrm{EnH}_{2}{ }^{2+}$ dari fasa gerak. Selain dipengaruhi oleh efek faktor kompetisi, penahanan juga dipengaruhi oleh pembentukan kompleks antar ion unsur tanah jarang dengan ligan terdeprotonasi yaitu tartrat. Ligan tartrat yang digunakan akan terdeprotonasi sehingga melepaskan ion hidrogen dan membentuk kesetimbangan yang menggangu ikatan antara ion unsur tanah jarang dengan gugus karboksilat membentuk suatu kompleks yang memilki muatan netral sehingga dapat dilepaskan dari fasa diam dan menuju detektor untuk dianalisis.

Fasa diam yang digunakan yaitu silika gel yang terikat secara kimia dengan gugus asam kuat sehingga kolom yang digunakan disebut kolom penukar kation kuat. Gugus asam kuat yang dimaksud yaitu $\mathrm{HSO}_{3}{ }^{-}$. Mekanisme pemisahan neodimium dan praseodimium dalam kolom yaitu gugus $\mathrm{HSO}_{3}{ }^{-}$yang terikat pada silika gel mengikat $\mathrm{EnH}_{2}{ }^{2+}$ kemudian $\mathrm{HSO}_{3}{ }^{-}$ mengikat $\mathrm{M}^{+}$dan $\mathrm{EnH}_{2}{ }^{2+}$ yang sebelumnya terikat ini lepas dan keluar dari kolom, kemudian $\mathrm{M}^{+}$yang terikat pada $\mathrm{HSO}_{3}{ }^{-}$ dilepas oleh ligan yang selanjutnya dibawa oleh eluen hingga mencapai detektor dengan waktu retensi yang berbeda-beda. Hal ini didasarkan pada perbedaan afinitas relatif antara kompleks logam-ligan dengan gugus $\mathrm{HSO}_{3}{ }^{-}$(dalam Framudia 2004).

Setelah diperoleh hasil pemisahan yang baik dari masing-masing unsur logam tanah jarang pada kondisi optimum, dilakukan analisis terhadap sampel monasit dan senotim hasil pengolahan dowa mining. Sampel dipreparasi dengan cara mendekstruksi terlebih dahulu sampel dengan asam nitrat untuk neodimium praseodimium, serium dan lantanum hingga larutan menjadi jernih, sehingga diperoleh kromatogram hasil pemisahan unsur tanah jarang dari larutan sampel pada sampel monasit dapat dilihat dalam Gambar 2.

\section{Pemisahan UTJ dalam hasil olah monasit}

Besarnya konsentrasi asam nitrat yang terkandung dalam analit ternyata mengganggu integrasi puncak-puncak dari unsur tanah jarang, hal ini terlihat pada kromatogram sampel monasit $(0,05$ gram dalam $100 \mathrm{~mL}$ ) menunjukkan bahwa puncak unsur tanah jarang berimpit dengan puncak asam sulfat sehingga pemisahan unsur tanah jarang tidak seperti yang diharapkan. Dengan demikian diperlukan pemisahan selanjutnya dengan cara mengurangi konsentrasi asam nitrat yaitu dengan mengencerkan sampel monasit tersebut sehingga konsentrasi asam nitratnya lebih kecil, hal ini ditunjukkan gambar bahwa puncak dari neodimium, praseodimium, serium dan lanthanum terpisah satu sama lain dengan waktu retensi berturut turut: 9,$97 ; 11,61 ; 14,06$; 16,89 menit.

\section{Analisis Kuantitatif Kandungan UTJ dalam Monasit}

Untuk menentukan kandungan masingmasing unsur tanah jarang yang terkandung dalam monasit dan senotim dapat dilakukan dengan menggunakan kurva baku dari hasil perhitungan luas puncak standar neodimium dan praseodimium dengan variasi konsentrasi yaitu: 5 ppm, 10 ppm, 20 ppm, dan 40 ppm. 
Analisis Kuantitatif Neodimium, Praseodimium, Cerium, Dan Lantanum Dalam Monasit Dengan Kckt Pertukaran Ion

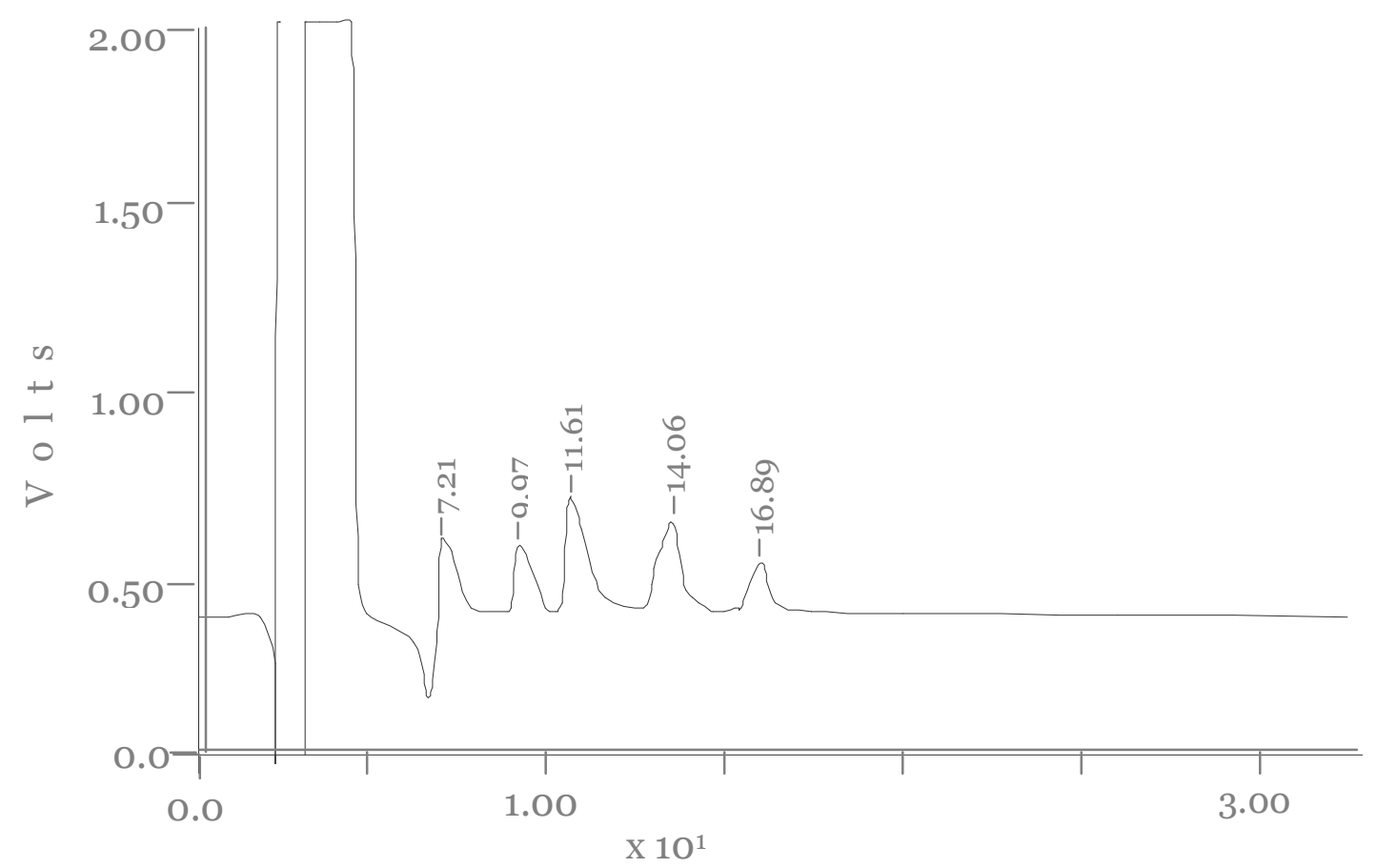

Gambar 2 Kromatogram Neodimium, Praseodimium, Serium dan Lantanum dalam Monasit Sebanyak 0,025 gram dalam $100 \mathrm{~mL}$.

Berdasarkan hasil luas puncak dari masing masing unsur tanah jarang (neodimium, praseodimium, serium dan lantanum) dengan konsentrasi yang berbeda-beda tersebut dapat digunakan sebagai kurva baku luas puncak terhadap konsentrasi. Sehingga kandungan masing-masing unsur tanah jarang dalam monasit dapat ditentukan).

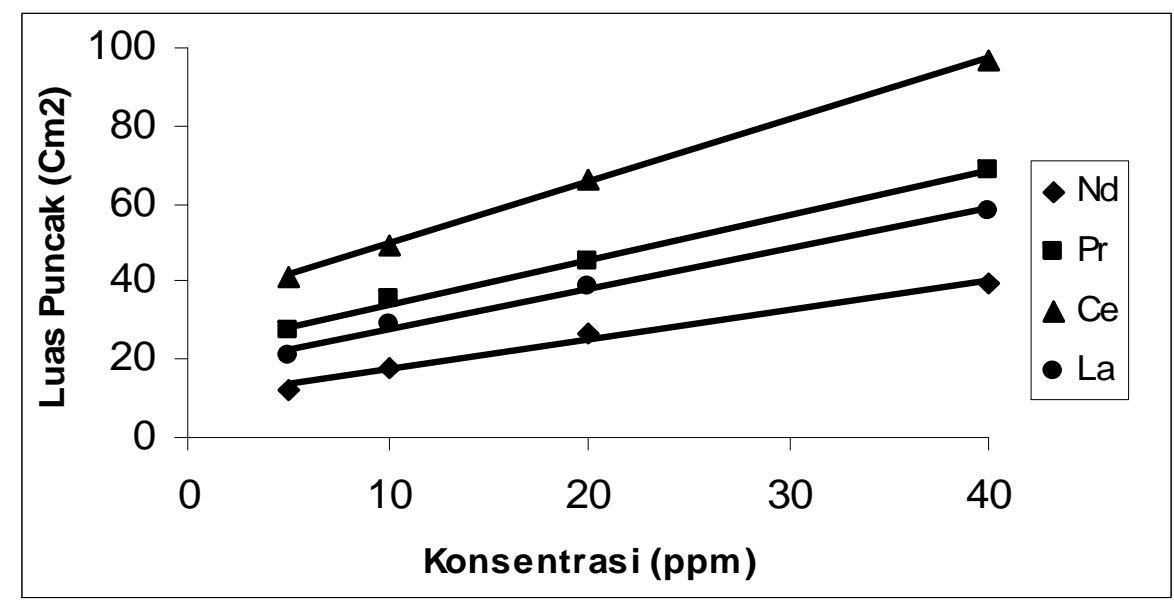

Gambar 3. Kurva Baku dari Luas Puncak Campuran Standar Neodimium, Praseodimium, Serium, dan Lantanum Terhadap Konsentrasi 
Analisis Kuantitatif Neodimium, Praseodimium, Cerium, Dan Lantanum Dalam Monasit Dengan Kckt Pertukaran Ion

Tabel 1. Persamaan Garis Untuk Standar Neodimium, Prasodimium, Serium, dan Lantanum

\begin{tabular}{lccc}
\hline \multicolumn{1}{c}{ Standar } & Memenuhi Persamaan Garis & Persamaan Garis regresi linear & $\mathrm{R}$ \\
\hline Neodimium & $\mathrm{Y}=\mathrm{bx}+\mathrm{a}$ & $\mathrm{Y}=0.76 \mathrm{x}+9.91$ & 0.9954 \\
Praseodimium & $\mathrm{Y}=\mathrm{bx}+\mathrm{a}$ & $\mathrm{Y}=1.16 \mathrm{x}+22.42$ & 0.9988 \\
Serium & $\mathrm{Y}=\mathrm{bx}+\mathrm{a}$ & $\mathrm{Y}=1.59 \mathrm{x}+33.69$ & 0.9998 \\
Lantanum & $\mathrm{Y}=\mathrm{bx}+\mathrm{a}$ & $\mathrm{Y}=1.04 \mathrm{x}+17.31$ & 0.9966 \\
\hline
\end{tabular}

Berdasarkan hasil kurva baku tersebut diperoleh suatu persamaan garis linear yang dapat dijadikan suatu persamaan untuk menentukan kandungan neodimium dan praseodimium, dalam monasit. Sampel monasit dianalisis dan diperoleh suatu kromatogram yang dapat dihitung luas puncaknya selanjutnya ditentukan besar kandungan masing-masing unsur tanah jarang dalam sampel. Dari hasil analisis sampel monasit. Dari gambar tersebut diperoleh harga rata-rata luas puncak neodimium, praseodimium,serium dan lantanum berturut turut yaitu: 18,$73 ; 45,58$; 50,$61 ; 28,25 \mathrm{~mm}^{2}$ untuk sampel monasit Berdasarkan hasil perhitungan, diperoleh hasil bahwa kandungan neodimium, praseodimium, serium dan lantanum dalam monasit berturut-turut yaitu: 11,$64 ; 19,96$; 10,$66 ; 10,55 \mathrm{ppm}$. Dari hasil tersebut jika diubah dalam konsentrasi persen berat per berat diperoleh hasil analisis bahwa kandungan neodimium, dan praseodimium dalam monasit $(\% \quad \mathrm{~b} / \mathrm{b})$ sebesar: $4,580 \pm 0,003 ; \quad 7,860 \pm 0,002 ; \quad 4,200 \pm 0,003$; $4,160 \pm 0,005 \%$

\section{KESIMPULAN}

Berdasarkan hasil penelitian dapat disimpulkan sebagai berikut:

1. Metode KCKT pertukaran ion dapat digunakan untuk memisahkan dan menentukan kandungan neodimium dan praseodimium dalam monasit.

2. Pemisahan ini dilakukan pada kondisi optimum kromatografi menggunakan fasa gerak etilendiamin $(1,50 \mathrm{mM})$ dengan ligan pengompleks asam tartrat $(2,00 \mathrm{mM}), \mathrm{pH} 4,5$, kecepatan alir 0,8 $\mathrm{mL} / \mathrm{menit}$, dan volume injeksi $10 \mu \mathrm{L}$.

3. Kandungan neodimium, praseodimium, serium, dan lantanum dalam monasit $(\mathrm{b} / \mathrm{b})$ berturut turut yaitu: $\quad 4,580 \pm 0.003 ; \quad 7,860 \pm 0,002$; $4,200 \pm 0,003 ; 4,160 \pm 0,005 \%$

\section{UCAPAN TERIMA KASIH}

Disampaikankan terima kasih sebesarbesarnya kepada Fakultas Farmasi Universitas Mulawarman yang telah memberikan bantuan dana Penelitian.

\section{DAFTAR PUSTAKA}

1. Cochrane, R.A. 1996, Determination of Trace Metal in Solution by Ion Chromatography. Trace Metal Removal from Aqueuos Solution. Proceding of Symposium of the Annual Chemical Congress. The Industrial Division of the Royal Society of Chemistry; London. 197219

2. Cotton, F.A.; Wilkinson, G.S.; \& Gaw, P.L. 1995, Basic Inorganic Chemistry; New York: John and Willey Sons.

3. Framudia, S. 2004, Pemisahan Serium Hasil Olah Pasir Senotim Secara Kromatografi Penukar Kation Lemah; Jatinangor, Skripsi, FMIPA UNPAD.

4. Garcia, R.V.; Hidricka, A.; Petruka, J.; \& Havel, J. 2001, Separtion of Rare Earth Elements by High Performance Liquid Chromatography Using A Covalent Modified Silica Gel Column. Anal. Chem. Act. 439: 247253. 
5. Haddad, P.R.; \& Peter, E.J. 1987, Ion Chromatography. Principles and Application; Netherland: Elsevier Science Publisher.

6. Haddad, P.R.; \& Jackson, P.E. 1990, Ion Chromatography. J. Chromatogr Lib. 46, 15 200; New York: Elsevier Science Pub.

7. Shuai, Q.; Qin, Y.; Hu, B.; \& Xiong, H. 2000, Determination of Rare Earth Impurities in High
Purity La-Oxide Using Electrothermal Vaporization/ICP-AES after HPLC Separation. J. Anal. Sci 16.

8. Snyaer, L. R.; Glojeh, J. L.; \& Kirland, J. J. 2003, Practical HPLC Method Development. Second edition; New York: John Willey and Sons Inc. 